\title{
Influence of Parenting Styles on In-School Adolescents Achievement Goal Orientation and Academic Achievement
}

\author{
Obi Ifeoma E., Okeke Therese U. \\ Anambra State University, Uli, Nigeria
}

\begin{abstract}
The aim of the study was to examine the influence of parenting styles on academic achievement and the extent to which the variable of goal orientation mediate the influence of parenting styles on academic achievement of in-school adolescents. Three research questions and three hypotheses guided the study. Eight hundred and thirteen in-school adolescents and their parents constituted the sample. Two sets of questionnaires were used to collect data for the study while hierarchical multiple regression analysis was used to analyze the data. The researchers found that authoritarian and authoritative parenting styles made significant contribution to students' academic achievement. While performance approach made significant positive contribution, performance avoidance had negative contribution to academic achievement. It was also found that achievement goal orientation partially mediated the influence of parenting style on academic achievement. The implications for practice were put forward. Keywords: parenting styles, achievement goal orientation, academic achievement, adolescents, secondary education
\end{abstract}

\section{Introduction}

Academic achievement of adolescents has been one of the important concerns for societies, institutions and individuals. The prediction of academic achievement and the examination of factors relating to the academic achievement are topics of huge interest at different educational levels. As documented in research literature, adolescent achievement has been associated with several factors such as delinquency (Okorodudu, 2010); and educational and occupational attainment (Marjoribanks, 2005). Other important variables that can influence academic achievement of adolescents are achievement goal orientation and parenting styles.

Persistent poor academic performance of adolescents in the Nigerian secondary schools has been a source of worry to parents, teachers, educators, educational institutions, and the Nigerian government (Adeyegbe, 2002; Akinsolu, 2010; Asikhia, 2010; Adeyemi, 2011; Olorundare, 2011; Oluwatimilehin \& Owoyele, 2012). This is so because success or failure at this level determines one's chances of gaining admission into the university, a goal that is desired and sought after by most parents, teachers and schools. It is not surprising therefore that appalling strategies such as students' patronage of "miracle centres" (examination malpractice syndicates), schools and teachers aiding and abetting students' examination malpractice, among other similar practices are widespread (Ibrahim \& Usman, 2008).

Increasing adolescents' academic achievement has been one of the abiding interests of most Nigerian educators and researchers. Therefore, factors that positively or negatively impact on adolescents' academic

Obi Ifeoma E., senior lecturer, Department of Educational Foundation, Anambra State University.

Okeke Therese U., senior lecturer, Department of Educational Foundation, Anambra State University. 
achievement have attracted huge research interests in the recent past. Most of these studies focused on schools characteristics and teacher behaviour (Akiri \& Ugborugbo, 2009; Atanda \& Jaiyeoba, 2011; Owoeye \& Yara, 2011; Alimi \& Balogun, 2010); students' home background and family structure (Ihebereme \& Maduewesi, 2007; Adesoji \& Olatunbosun, 2008; Ogunkola \& Olatoye, 2010); student characteristics and study habits (Oluwatimilehin \& Owoyele, 2012; Ayodele \& Adebiyi, 2013). However the dynamics of other important variables that can influence academic achievement of adolescents such as achievement goal orientation and parenting styles have received little research attention in Nigeria.

Achievement goal orientation is the purpose that motivates students within the academic setting (Wolters, 2004). Elliot (1999) posited that adolescents respond to difficult and challenging situations with one of three different goal orientations: mastery, performance-approach, and performance-avoidance. Mastery orientation focuses on engaging in tasks for the sake of improvement in learning. Performance-approach orientation focuses on engaging in task for the sake of outperforming others while performance-avoidance focuses on avoiding tasks for the sake of preventing embarrassment or shame.

In addition to the influence of goal orientation on academic achievement of adolescents researchers have emphasized the impact of parenting styles on academic achievement. Baumrind (1967) developed a parenting style typology which consists of authoritarian, authoritative and permissive parenting styles. Authoritative parents are characterized as having a high degree of responsiveness and warmth. They combined mutual reciprocation toward their children in setting rules and limits as well as exhibit high level of control and demandingness. Authoritarian parents, on the other hand, are highly controlling and demanding in their use of authority. They do not condone disobedience and confrontation from their children with regards to set down rules, regulations and decisions. Authoritarian parents are also not responsive. Permissive parents are either indulgent or neglectful. Indulgent parents are characterized by a high degree of responsiveness and warmth, but exhibit low control or demandingness in setting rules or limits while neglectful parents do not exhibit any degree of either responsiveness or warmth nor do they exercise any degree of control or demandingness.

Parenting style has been examined in many international studies as a strong predictor of adolescent academic achievement (Star, 2011; Wintre \& Yaffe, 2000). Some researchers found that the authoritative parenting is associated with higher academic achievement (Mattern, 2005; Aunola, Stattin, \& Nurmi, 2000). However, reports across different findings have not been inconsistent across culture, suggesting a possible cultural difference (Spera, 2005; Hae- Seong \& Bauer, 2002).

Consequently, research in a different cultural context would be relevant. In Nigeria, recent empirical studies on parenting styles focus on its influence on problem behaviour (Maliki \& Inokoba, 2011; Tunde-Ayinmode \& Adegunloye; 2011; Omolola, 2011; Akanbi \& Oyewo, 2013; Umo, 2013) while a few that addressed its relationship with students' academic achievement were done at the primary school level (Fakeye, 2008; Shobola, Omoregbe, \& Olufemi, 2012). Although Ogunleye, Omirin, and Balogun (2013) examined the influence of parenting style on secondary school students' academic achievement using a small sample of secondary school students in one school, there is need to not only extend this study but also ascertain whether the influence of parenting style on academic achievement is more direct or mediated by students' achievement goal orientation. Therefore, this work seeks to examine the contribution of parenting styles to students' goal orientation and academic achievement on one hand and the contribution of the students' goal orientation to academic achievement on the other hand. It will also explore the mediating role of achievement goal orientation in the contribution of parenting styles to academic achievement. 


\section{Hypotheses}

H1: Parenting styles will not significantly contribute to in-school adolescents' goal orientation (mastery goal, performance approach and performance avoidance);

H2: Parenting styles will not significantly contribute to in-school adolescents' academic achievement;

H3: Achievement goal orientation will not significantly contribute to in-school adolescents' academic achievement;

H4: Achievement goal orientation (mastery, performance approach and performance-avoidance) will not mediate contribution of parenting styles to in-school adolescents' academic achievement.

\section{Theoretical Background}

Evidence from research studies, most of which were international, indicate direct and indirect influences of parenting styles on students' academic achievement and other factors associated with academic achievement such as goal orientation and motivation. These constituted the theoretical basis for this research.

\section{Parenting Styles, Goal Orientations, and Academic Achievement}

Parenting style is described as a combination of attitudes toward a child that are communicated to the child which create an emotional climate expressed by parents' behaviour and which influences the child's (Darling \& Steinberg, 1993). Baumrind (1967) developed a typology of parenting styles which was used to examine the differential impact of authoritative, authoritarian and permissive parenting on academic achievement of adolescents. Authoritarian parents are highly controlling in their use of authority but are not responsive. They have high expectations of maturity and want to control their child's behaviour and attitudes; and do not condone disobedience and confrontation from their children with regards to set down rules, regulation, traditions and decision. Authoritative parents are warm and communicate well with their children. They are both responsive to the needs of their children and demanding in that they set expectations for their children. This type of parenting style permits children enough freedom of expression so that they can develop a sense of independence without extending beyond reasonable limits. Permissive parents on the other hand are high in warmth but lack control towards their children. They are more responsive to the needs of their children but less demanding. Permissive parents are lenient, do not require mature behaviour, allow considerable self-regulation and avoid confrontation (Macoby \& Martin, 1983).

The foregoing suggests that parenting styles may be linked to children's motivational forces. Ginsburg and Bronstein (1993) observe that over- and under-controlling parenting styles were linked to extrinsic motivation, while parental encouragement in response to grades and autonomy-supporting family styles were linked to intrinsic motivation. Intrinsic motivation relates to the tendency for a student to engage in a task for the interest and desire to learn rather than external forces. Intrinsic motivation has been associated with mastery goal orientation while external motivation is associated with performance avoidance goal orientations (Ames, 1992; Church, Elliot, \& Gable, 2001).

Baumrind's (1971) proposition that certain parenting styles such as permissive parenting has the potentials for low social and cognitive competence among children have been subjected to empirical investigation. Considerable number shows a relationship between parenting styles and academic achievement. Several studies in the literature found that the authoritative parenting style was positively associated with higher academic achievement while authoritarian and permissive parenting styles were negatively associated with high academic 
achievement (Aunola, Stattin, \& Nurmi, 2000; Walker, 2010). These are likely because of the link between parenting styles and children's motivational outcomes such as achievement goal orientations.

\section{Goal Orientations and Academic Achievement}

Goal Orientation emphasizes the purpose for which an individual participates in an activity or engages in a task. Goal orientations are regarded as integrated patterns of motivational beliefs that represent different ways of approaching, engaging in, and responding to achievement-related activities (Ames, 1992). Elliot (1999) posited three types of achievement goals orientation namely mastery orientation, performance-approach orientation and performance-avoidance orientation.

Mastery goal focused on the development of competence or the attainment of task mastery (Dweck, 2000). Adolescents who possess a mastery goal orientation seek to understand the material they are learning, master a skill, and increase their competence through their own effort. This type of goal orientation helps them to maintain their competence in the face of failure, to eliminate negative effect such as anxiety, to lessen the probability of distracting thoughts, and to free up cognitive capacity, which in turn leads to more cognitive engagement and higher achievement outcomes (Jewrell, 2006).

Adolescents possessing a performance approach or performance-avoidance focus on their ability rather than the task, are mainly concerned with high marks in tests and examinations as a demonstration of their ability. They work to maintain their position relative to others in the class and strive to gain favourable judgments of their competence and to avoid negative judgment (Dweck, 200). Adolescents who possess performance approach goal are positively motivated to try to do better than others. While those who possess performance-avoidance goal are negatively motivated to try avoiding failure or appearing incompetent (Elliot, 2005).

Several studies in literature have indicated that different goal orientations can lead to different educational outcomes. Mastery goal orientation will lead to many positive outcomes such as attribution of success to effort (Ames \& Archer, 1988), interest in school work (Pintrich, 2000), academic self-efficacy (Roeser, Midgley \& Urdan, 1996), persistence in challenging tasks (Dweck, 2000). Performance approach is also related to a number of positive outcomes such as use of cognitive strategies and high academic achievement (Pintrich, 2000; Church, Elliot, \& Gable, 2001). Performance-avoidance goals are related to negative outcomes such as superficial learning strategies (Elliot \& Church, 1997), threat-related effect while studying (Skaalvik, 1997), reluctance to seek academic assistance (Newman, 1998), withdrawal from effort in the face of failure (Dweck \& Leggelt, 1998) and anxiety before and during examination (Elliot \& Harackiewicz, 1996).

Despite the supportive evidence by researchers on the influence of achievement goals on academic achievement, there still remain some contradictions in the research literature. Some studies have indicated the negative effects of performance-approach goals on academic achievement despite previous findings that postulate the positive influence of performance-approach on academic achievement (Linnebrink, 2005; Sideridis, 2003).

A number of research evidence suggests that parenting styles and students' goal orientation are predictors of academic achievement (Duff, Boyle, Dunleavy, \& Ferguson, 2004; Elliot \& McGregor, 2002). But these variables and their roles in determining academic achievement have not been sufficiently studied in Nigeria. Since the identification of factors which will influence students' academic achievement is very important, it is necessary to investigate the influence of parenting styles on in-school adolescents' academic achievement and how achievement goal orientation mediate the influence of parenting styles to academic achievement. 


\section{Method}

\section{Participants}

The participants were 813 in school adolescents and their parents. These students are at the senior level in secondary schools in Awka Education Zone of Anambra State of Nigeria. The sample of students consisted of 440 males and 373 females and had mean age of 17 years in a range of 14 to 20 years. Their parents consisted of 468 males and 345 females. Greater proportion (517) of the parents' educational qualification was below first degree.

\section{Instrument}

Two sets of questionnaires were used for data collection - the parenting style index and Students' Goal Orientation Questionnaire. Parenting style index that was used to measure parenting styles was adapted from Parenting Practices by Robinson, Mandleco, Olsen, and Hart (1995). The original instrument of 62 items had 27 items relating to authoritative parenting style, 20 items relating to authoritarian parenting style and 15 items relating to permissive parenting styles. The questionnaire used for this study was 50 -item with 15 relating to authoritarian parenting style, 24 relating to authoritative parenting style and 11 items relating to permissive parenting style. The response format was modified from five to a four-point Likert format of: "Strong disagree" (1), "Disagree" (2), "Agree" (3), and "Strongly agree" (4). Some of the words used in the questionnaire were changed for better understanding for the target population. For example, instead of "I bribe my child to bring about compliance"; the word "obedience" was used. The expression, "I am "unsure"” was substituted for "I appear unsure" and instead of "I emphasize the reasons for rules", "I explain the reasons for obeying rules" were used. Considering the cultural differences, the researchers decided to establish the reliability of the instrument using a sample of 40 parents from the same education zone. Good reliability was recorded as the results of internal consistency reliability coefficients of 0.81 for authoritative parenting style, 0.78 for authoritarian parenting style, and 0.76 for permissive parenting style was obtained.

The students' goal orientation questionnaire was adapted from previously used scales developed by Midgley et al. (1998). It comprises three sub-scales; mastery, performance approach and performance avoidance with six items for each sub-scale. Its response pattern was based on a five-point Likert format ranging from 5 ("Strongly agree") to 1 ("Strongly disagree"). Its reliability was also tested using sample of 30 students in one of the secondary schools in the Awka education zone. The analysis yielded internal consistency reliability coefficients of 0.80 for mastery, 0.82 for performance approach, and 0.75 for performance avoidance. These were regarded as high enough for the study.

The cumulative annual average of the students' results were used to measure their academic achievement. Cumulative results are the overall academic performance of all courses completed by the students. The cumulative results were used as this would portray their annual performance in the three academic terms during the previous year.

\section{Data Collection Procedure}

Instruments for data collection were distributed by the two researchers assisted by two assistants. To assure the participants of confidentiality, no names were used, instead the questionnaires for the students and their parents were coded using the classes A, B, C, and serial numbers on the class score sheets. The questionnaire on parenting practices meant for the parents were enclosed each in an envelope. Student A1 on the score sheet collected questionnaire A1 on goal orientation meant for students and collected his/her parent's (mother or father) questionnaire A1 on parenting style meant only for parents. The questionnaire for the parents already coded were 
taken home by the students during their one month vacation and brought back by the students at the end of the vacation. The need to be honest and objective in filling the questionnaire was explained to the students while assuring them that there were no correct or wrong answers. The students filled their own questionnaire at the end of which they were collected by the researchers and their assistants. The cumulative results of the students were released to the researchers by the Deans of Studies of the respective schools.

\section{Method of Data Analysis}

Hierarchical multiple regression was used to analyze the data. This method involves entering the predictors and mediating variable in steps to determine both the main effects of parenting styles and mediating role of achievement goal orientation in the relationship between parenting styles and academic achievement. The multiple correlation $(R)$ and the $\left(R^{2}\right)$ was used to evaluate the strength of the joint contribution of both the three parenting styles (authoritative, authoritarian and permissive) and the mediating variable (achievement goals). The regression coefficients or Beta weights $(\beta)$ will be used to judge the strength of the contribution of each of the predictors.

\section{Results}

\section{Preliminary Analysis}

Table 1 presents the mean scores and standard deviation of predictors, mediating and outcome variable. Respondents' mean score of 36.39 on authoritarian parenting style on a measure that ranged between 15 and 60 shows a moderate use of this style. The mean score of 20.84 on permissive style on a scale ranging between 11 and 44 indicates that their use of this style is below average while mean score of 69.66 on authoritative parenting style on a scale ranging between 24 and 96 shows relative high use of this method.

In terms of Students Goal Orientation, mean scores of 26.02, 22.88, and 19.06 on a scale ranging from 6-30 that all are above the theoretical mean (18) and that students adopt multiple goal orientation even though they seem to adopt master goal orientation more than the others.

Table 1

Means and Standard Deviations of Parenting Styles, Achievement Goal Orientation, and Academic Achievement

\begin{tabular}{lllc}
\hline & $N$ & Mean & Std. Dev. \\
\hline Authoritarian parenting style & 813 & 36.39 & 7.30 \\
Permissive parenting style & 813 & 20.84 & 8.33 \\
Authoritative parenting style & 813 & 69.66 & 12.66 \\
Mastery goal & 813 & 26.02 & 2.89 \\
Performance approach goal & 813 & 22.88 & 4.66 \\
Performance avoidance goal & 813 & 19.06 & 5.40 \\
Academic achievement & 813 & 54.43 & 9.38 \\
\hline
\end{tabular}

As shown by the Table 2, there was no risk of multicollinearity as most of the variables were not highly correlated with each other. As would be expected, authoritarian parenting style was negatively correlated with authoritative $(r=-0.24)$ while authoritative was negatively correlated with permissive parenting style. Authoritarian style had significant positive correlation with performance approach $(r=0.35)$ and academic achievement $(r=0.30)$ and a significant negative correlation with performance avoidance $(r=-0.17)$. On the other hand, authoritative style had significant negative correlation with performance approach $(r=0.10)$ and academic achievement $(r=0.16)$.

Regarding the correlation between goal orientations and academic achievement, mastery approach had no 
significant correlation with academic achievement $(r=0.04)$, performance approach had significant positive correlation with academic achievement $(r=0.42)$ while performance avoidance had significant negative correlation with academic achievement $(r=-0.27)$.

Table 2

Correlations Between Parenting Style, Achievement Goal Orientation, and Academic Achievement

\begin{tabular}{lccccccc}
\hline Variables & 1 & 2 & 3 & 4 & 5 & 6 & 7 \\
\hline 1. Authoritarian & - & & & & & & \\
2. Permissive & 0.02 & - & - & & & & \\
3. Authoritative & $-0.24^{*}$ & $-0.42^{*}$ & & & & & \\
4. Mastery & -0.03 & 0.03 & 0.02 & - & & & \\
5. Performance approach & $0.35^{*}$ & -0.02 & $-0.10^{*}$ & 0.00 & - & & \\
6. Performance avoidance & $-0.17^{*}$ & $-0.13^{*}$ & $0.35^{*}$ & -0.03 & $-0.09^{*}$ & - & - \\
7. Academic achievement & $0.30^{*}$ & 0.02 & $-0.16^{*}$ & 0.04 & $0.42^{*}$ & $-0.27^{*}$ & - \\
\hline
\end{tabular}

\section{Substantive Analysis}

H1: Parenting style will not significantly contribute to in-school adolescents' goal orientation (mastery goal, performance approach and performance avoidance).

Parenting styles (authoritarian, permissive and authoritative) had joint significant contribution to the variance in performance approach $\left(R=0.35, R^{2}=0.12, F=29.62\right)$ and performance avoidance $\left(R=0.36, R^{2}=\right.$ $0.13, F=41.00$ ) but made no significant contribution to mastery goal orientation. In terms of individual contribution of parenting styles to performance approach and performance avoidance, only authoritarian parenting style made significant positive contribution $(\beta=0.34)$ whereas it made significant but negative contribution to performance avoidance $(\beta=-0.09)$, authoritative parenting styles had significant positive contribution to performance avoidance $(\beta=0.31)$.

Table 3

Multiple Regression of Parenting Styles on Students' Goal Orientations

\begin{tabular}{|c|c|c|c|c|c|c|c|c|c|}
\hline \multirow{2}{*}{ Variables entered as predictors } & \multicolumn{3}{|c|}{ Mastery goal } & \multicolumn{3}{|c|}{ Performance approach } & \multicolumn{3}{|c|}{ Performance avoidance } \\
\hline & $B$ & SE B & $\beta$ & $B$ & SE B & $\beta$ & $B$ & SE B & $\beta$ \\
\hline Constant & 25.37 & $1 / 06$ & & 16.63 & 1.60 & & 11.39 & 1.84 & \\
\hline Authoritarian & -0.01 & 0.01 & -0.02 & 0.215 & 0.02 & $0.34^{*}$ & -0.07 & 0.03 & $-0.09^{*}$ \\
\hline Permissive & 0.02 & 0.01 & 0.04 & -0.03 & 0.02 & -0.05 & 0.01 & 0.02 & 0.01 \\
\hline Authoritative & 0.01 & 0.01 & 0.04 & -0.02 & 0.01 & -0.04 & 0.14 & 0.02 & $0.31^{*}$ \\
\hline$R$ & & & 0.05 & & & 0.35 & & & 0.36 \\
\hline$R^{2}$ & & & 0.00 & & & 0.12 & & & 0.13 \\
\hline$F$ & & & 0.73 & & & $37.21^{*}$ & & & $41^{*}$ \\
\hline
\end{tabular}

Note. "Significant.

H2: Parenting styles will not significantly contribute to in-school adolescents' academic achievement.

As shown in the Table 3, parenting styles (authoritarian, permissive and authoritative) made significant joint contribution to the variance in academic achievement $\left(R=0.32, R^{2}=0.10, F=29.62\right)$. The $R^{2}$ showed that parenting style explained $10 \%$ of the variance in academic achievement. It was therefore concluded that parenting style made significant contribution to in-school adolescents' academic achievement. In terms of individual contribution of the different parenting styles, Authoritarian style made the highest positive contribution $(\beta=0.27)$, followed by authoritative style $(\beta=-0.11)$ which made negative contribution to 
academic achievement. Permissive parenting styles did not make significant contribution.

H3: Achievement goal orientation will not significantly contribute to in-school adolescents' academic achievement.

Step 2 of the hierarchical multiple regression analysis shown in table 3, indicates that achievement goal orientation (mastery goal, performance approach and performance avoidance) made significant joint contribution to the variance in academic achievement $\left(R=0.48, R^{2}=0.23, F=81.85\right)$. The $R^{2}$ shows that achievement goal orientation explained $23 \%$ of the variance in academic achievement. It was therefore concluded that achievement goal orientation made significant contribution to in-school adolescents' academic achievement. Regarding the unique/individual contribution of each of the goal orientation, performance approach made the highest contribution as shown by its standardized beta weights $(\beta=0.40)$, followed by performance avoidance $(\beta=-0.23)$ that made significant negative contribution to academic achievement. Mastery goal did not make significant contribution $(\beta=0.03)$.

H4: Achievement goal orientation (mastery, performance approach and performance avoidance) will not mediate contribution of parenting style to in-school adolescents' academic achievement.

As shown in Step 3 of the hierarchical multiple regression analysis in Table 3, achievement goals orientation jointly made an incremental variance of $15 \%$ as shown by the change $\left(R^{2}=0.15\right)$. In terms of its unique mediating effect on each of the parenting styles, when achievement goal orientation was added to the model, the contribution of authoritarian parenting styles to academic achievement changed from $\beta=0.27$ to $\beta=$ 0.14 ( 0.13 decrease) while the contribution of authoritative parenting styles changed from -0.11 to -0.03 ( -0.8 decrease). Although the contribution of authoritarian style was still significant, authoritative style was statistically non-significant. It was concluded that achievement goal orientation mediated the relationship between parenting styles and academic achievement (See Table 4).

Table 4

Hierarchal Multiple Regression of Academic Achievement on Parenting Style and Achievement Goal Orientation

\begin{tabular}{|c|c|c|c|c|c|c|c|c|}
\hline Variables entered as predictors & $B$ & SE B & $\beta$ & $R$ & $R^{2}$ & Change in $R^{2}$ & $F$ & $F$ Change \\
\hline \multicolumn{9}{|l|}{ Step 1: Parenting style } \\
\hline Constant & 48.30 & 3.26 & & & & & & \\
\hline Authoritarian & 0.35 & 0.04 & $0.27^{*}$ & & & & & \\
\hline Permissive & -0.04 & 0.04 & -0.04 & & & & & \\
\hline Authoritative & -0.08 & 0.03 & $-0.11^{*}$ & 0.32 & 0.10 & 0.09 & $29.62^{*}$ & - \\
\hline \multicolumn{9}{|l|}{ Step 2: Goal orientation } \\
\hline Constant & 40.91 & 3.22 & & & & & & \\
\hline Mastery & 0.11 & 0.10 & 0.03 & & & & & \\
\hline Performance Approach & 0.80 & 0.06 & $0.40^{*}$ & & & & & \\
\hline Performance Avoidance & -41 & 0.05 & $-0.23^{*}$ & 0.48 & 0.23 & 0.23 & $81.85^{*}$ & - \\
\hline \multicolumn{9}{|c|}{ Step 3: Parenting style \& goal orientation } \\
\hline Constant & 37.35 & 4.11 & & & & & & \\
\hline Authoritarian & 0.18 & 0.04 & $0.14^{*}$ & & & & & \\
\hline Permissive & -0.02 & 0.04 & -0.02 & & & & & \\
\hline Authoritative & -0.02 & 0.03 & -0.03 & & & & & \\
\hline Mastery & 0.13 & 0.10 & 0.040 & & & & & \\
\hline Performance approach & 0.71 & 0.07 & $0.35^{*}$ & & & & & \\
\hline Performance avoidance & -0.36 & 0.06 & $-0.21^{*}$ & 0.50 & 0.25 & 0.15 & $44.93^{*}$ & $54.37^{*}$ \\
\hline
\end{tabular}

Note. ${ }^{*}$ Significant. 


\section{Discussion of Findings}

The results of this study show that authoritarian and authoritative parenting styles made significant positive contribution to two of the three goal orientations-performance approach and performance avoidance. This is consistent with the propositions made by Ginsburg and Bronstein (1993) which suggests that the level of parental control influences a child's adoption of intrinsic or extrinsic motivations to tasks and activities.

Another interesting finding reveals that parenting styles made significant contribution to in-school adolescents' academic achievement. The result of the present study did not support the work of Jewrell (2006) who found that parenting styles were not significantly related to academic achievement. In terms of individual contribution of different parenting styles, the study found that authoritarian style made the highest positive contribution, authoritative style made negative contribution, while permissive style did not make significant contribution.

Results of the present study was inconsistent with the findings by Jones, Forehand, and Beach, (2000), Walker (2010) who found that authoritative parenting contribute to higher academic achievement; whereas authoritarian and permissive parenting lead to lower academic achievement. One of the plausible reasons for this situation is that parenting style may be mediated by other individual factors that may strengthen or contribute to its explanation of academic achievement (Fang, Xiong, \& Guo, 2003). Moreover, several researchers contended that the effect of parenting style on academic achievement was not consistent across cultures, ethnicity or socioeconomic status (Spera, 2005; Hae-song \& Baucer, 2002).

The study also found that among the three goal orientations, two (performance-approach, performance-avoidance) made significant contribution to academic achievement while mastery goal did not. This finding failed to support previous research results (e.g., Pintrich, 2000) which suggest that mastery goal contributes to higher academic achievement. One reason for this finding may be that in-school adolescents are positively motivated to do better than their classmates so that they will be recognized as being competent by their parents.

The study also revealed that goal orientation jointly made an incremental variance to parenting styles in explaining academic achievement. Significant changes in $R^{2}$ occurred when goal orientation was added to parenting styles in the regression model. In terms of its unique mediating effect on each of the parenting styles, the contribution of authoritative parenting to academic achievement was fully mediated while authoritarian parenting was partially mediated. This is an indication that authoritarian parenting still contributes positively to academic achievement even when the influence of goal orientation was accounted for. This is inconsistent with Sideridis' (2003) research finding indicating that performance approach has negative effective on academic achievement but consistent with the finding reported by Church, Elliot, and Gable (2001) which found that the performance approach orientation was positively related to actual performance at least in terms of final course grades for college students. A possible explanation for this could be due to much emphasis on obedience and strictness orientation of most in the Nigerian culture.

\section{Implications for Practice}

It is possible that the capacity of parenting styles to elicit either positive or negative outcome depends on the culture and the adolescent's characteristics. It is important that parents approach their parenting practices with this in mind. Parents should therefore engage in parenting skills that works best for them and their 
children.

Since parenting styles have positive relationship with educational outcomes such as goal orientation and academic achievement, schools, teachers and school counsellors should create a platform for developing parenting skills. This could be achieved by creating parental skills development centres in their schools. This practice has not been given much attention in Nigeria.

Counsellors should seek and keep information on students' parenting styles. This will enable them to help students develop and/or change goal orientation that would facilitate the positive learning outcome.

\section{Limitations of Study}

The measure of parenting style was derived from either students' mother or father. This may not give a balanced view of the parenting style. It is possible that there may be gender differences in parenting styles. Further study may derive this measure from both parents. Parents of relatively low education constituted the greater proportion of sample; this may have influenced the result. Further study may need to incorporate as control variable or moderator to eliminate possible confounding effects. Despite these limitations, this study has contributed to our understanding of the dynamics of parenting styles, goal orientation and academic achievement of adolescents at the secondary school level.

\section{References}

Adesoji, F. A., \& Olatunbosun, S. M. (2008). Student, teacher and school environment factors as determinants of achievement in senior secondary school chemistry in Oyo State, Nigeria. The Journal of International Social Research, 1(2), 13-34.

Adeyemi, T. O. (2011). A comparative study of students' academic performance in public examinations in secondary schools in Ondo and Ekiti States, Nigeria. Current Research Journal of Economic Theory 3(2), 36-42.

Akinsolu, A. O. (2010). Teachers and students' academic performance in Nigerian secondary schools: Implications for planning. Florida Journal of Educational Administration \& Policy, 3(2), 86-103.

Akiri, A. A., \& Ugborugbo, N. M. ( 2009). Teachers' effectiveness and students' academic performance in public secondary schools in Delta State, Nigeria. Stud. Home Comm Sci., 3(2), 107-113.

Alimi, O. S., \& Balogun, B. N. (2010). Teachers' attribute as correlate of students' academic performance in Geography in secondary schools in Ondo State. Pakistan Journal of Sciences, 7(5), 388-392.

Ames, C. (1992). Classrooms: Goals, structures, and Student motivation. Journal of Education Psychology, 84, 261-271.

Ames, C., \& Archer, J. (1988). Achievement goals in the classroom: Students' learning and motivation processes. Journal of Education Psychology, 80, 260-267.

Asikhia, O. A. (2010). Students' and teachers' perception of the causes of poor academic performance in Ogun State secondary schools: Implication for counselling for national development. European Journal of Social Sciences, 13(2), 229-242.

Atanda, A. I., \& Jaiyeoba, A. O. (2011). Effects of school-based quality factors on secondary school students' achievement in english language in South-Western and North-Central Nigeria. Journal of Emerging Trends in Educational Research and Policy Studies (JETERAPS), 2(2), 93-99.

Aunola, K., Stattin, H., \& Nurmi, J. E. (2000). Parenting styles and adolescents' achievement strategies. Journal of Adolescence, 23, 205-222.

Ayinmode, M F T., \& Adegunloye, O. A. (2011). Parenting style and conduct problems in children: A report of deliberate self poisoning in a Nigerian child. SAJP, 17(2), 60-63.

Ayodele, C. S., \& Adebiyi, D. R. (2013). Study habits as influence of academic performance of university undergraduates in Nigeria. Research Journal in Organizational Psychology \& Educational Studies, 2(3), 72-75.

Baumrind, D. (1967). Child care practices anteceding three patterns of pre-school behaviour. Genetic Psychology Monographs, 75, 43-88.

Baumrind, D. (1971). Current patterns of parental authority. Developmental Psychology Monographs, 75, 43-88.

Church, M. A., Elliot, A. J., \& Gable, S. L. (2001). Perceptions of classroom environment, achievement goals, and achievement outcomes. Journal of Educational Psychology, 93, 43-54. 
Darling, N., \& Steiberg, L. (1993). Parenting style as context: An integrative model. Child Development, 111, 487-496.

Duff, A., Boyle, E., Dunleavy, K., \& Ferguson, J. (2004). The relationship between personality, approach to learning and academic performance. Personality and Individual Differences, 36, 1907, 1920.

Dweck, C. S. (2000). Self-theories: Their role in motivation, personality and development. Lillington, N.C.: Taylor \& Francis

Dweck, C. S., \& Leggett, E. L. (1988). A social-cognitive approach to motivation and personality. Psychological Review, 95(2), 256-273.

Elliot, A. J. (1999). Approach and avoidance motivation and achievement goals. Educational Psychologist, 34, 169-189.

Elliot, A. J. (2005). A conceptual history of the achievement goal construct. In A. J. Elliot, \& C. S. Dweck (Eds.), Handbook of Competence and Motivation. New York: the Guilford Press.

Elliot, A. J., \& Church, M. A. (1997). A hierarchical model of approach and avoidance achievement motivation. Journal of Personality and social psychology, 54, 5-12.

Elliot, A. J., \& Harackiewicz, J. M. (1996). Approach and avoidance achievement goals and intrinsic motivation: A mediational analysis. Journal of Personality, 70(3), 461-476.

Fakeye, O. D. (2008). Parenting style and primary school pupils' reading achievement in South-Western Nigeria. Pakistan Journal of Social Sciences, 5(2), 209-214.

Fang, P., Xiong, D., \& Guo, C. Y. (2003). The effect of parenting styles on children's academic achievement. Psychological Science Ching, 26, 78-81.

Ginsburg, G. S., \& Bronstein, P. (1993). Family factors related to children's intrinsic/extrinsic motivational orientation and academic performance. Child Development, 64(5), 1461-1475.

Hae-Seong, P., \& Baucer, S. (2002). Parenting practices, ethnicity, socioeconomic status and academic achievement in adolescents. School Psychology International, 23(4), 386-397.

Ihebereme, C., \& Maduewesi, B. U. (2007). The relationship of home background and students academic performance in Orlu Education Zone of Imo State. Multidisciplinary Journal of Research Development, 9 ( 1), 31-35.

Jewrell, R. (2006). The relationship between parenting style and academic achievement and the mediating influences of motivation, goal orientation and academic self-efficacy. Electronic Theses, Treatises and Dissertations.

Jones, D. J., Forehand, R., \& Beach, S. R. H. (2000). Maternal and paternal parenting during adolescence: Forecasting early adult psychosocial adjustment. Adolescence, 38(139), 513-531.

Linnenbrink, E. A. (2005). The dilemma of performance-approach goals: The use of multiple goal contexts to promote students motivation and learning. Journal of Educational Psychology, 97(2), 197-213.

Macoby, E. E., \& Martin, J. A. (1983). Socialization in the context of the family: Parent-child interaction. Handbook of Child Psychology, 4, 100-101.

Mattern, R. A. (2005). College students' goal orientation and achievement. International Journal of Teaching and Learning in Higher Education, 17(1), 27-32.

Marjoribanks, K. (2005). Family background, academic achievement and educational aspirations as predictors of Australian young adults' education attainment. Psychological Reports, 96(3), 751-754.

Midglay, C., Kaplan, A., Middleton, M., Maehr, M., Urdan, T., Anderman, L., Anderman, E., \& Roeser, R. (1998). The development and validation of scales assessing students' achievement goal orientations. Contemporary Educational Psychology, 23, 113-131.

Maliki, A. E., \& Inokoba, P. K. (2011). Parental child rearing styles, parental marital relationship and students' attitude towards cultism in Niger Delta University Bayelsa State of Nigeria: Counselling implications. Journal of Social Science, 27(3), 209-214.

Newman, R. (1998). Students' help-seeking during problem-solving: Influences of personal and contextual goals. Journal of Educational Psychology, 90, 644-658.

Ogunkola, B. J., \& Olatoye, R. A. (2010). Students' inherent characteristics, parents' educational attainment and family size as predictors of academic achievement in integrated science. Research Journal of International Studies, 119-124.

Ogunleye, A. J., Omirin, M. S., \& Balogun, S. K. (2013). Males, females, parenting styles, and academic performance of secondary school students in Ekiti State Nigeria: An empirical investigation. Elixir Human Res. Mgmt., 56, 13626-13629.

Olorundare, A. S. (2011). Correlates of poor academic performance of secondary school students in the Science in Nigeria. Virginia, USA: Virginia State University.

Oluwatimilehin, J. T B., \& Owoyele, J. W. (2012). Study habits and academic achievement in core subjects among junior secondary school students in Ondo State, Nigeria. Bulgarian Journal of Science and Education Policy (BJSEP), 6(1), 155- 169. 
Omolola, L. A. (2011). The effects of parenting styles on students' disposition to violence in Osun State, Nigeria. Revista de cercetare [i interven] ie social, 32, 86-94.

Owoeye, J. S., \& Yara, P. O. (2011). School location and academic achievement of secondary schools in Ekiti State. Asian Social Science, 7(5), 170-175.

Okorodudu, G. N. (2010). Influence of parenting styles on adolescent delinquency in Delta Central Senatorial District. Edo Journal of Counselling, 3(1), 58-86.

Pintrich, P. E. (2000). An achievement goal theory perspective on issues in motivation terminology, theory, and research. Contemporary Education Psychology, 25, 92-104.

Roeser, R. W., Midgley, C., \& Urdan, T. C. (1996). Perception of the school psychological environment and early adolescents' psychological and behavioural functioning in school: The mediating role of goals and belonging. Journal of Educational Psychology, 88, 408-422.

Salami, S. O., \& Alawode, E. A. (n.d.). Influence of single-parenting on the academic achievement of adolescents in secondary schools: Implications for counseling.

Shobola, A., Omoregbe, S., \& Olufemi, O. O. (2012). Assessment of parenting styles on school attendance and academic performance of nomadic children in selected settlements in Nigeria. Journal of Educational and Social Research, 2(3).

Skaalvik, E. (1997). Self-enhancing and self-defeating ego orientation: Relations with task avoidance orientation, achievement, self-perceptions and anxiety. Journal of Educational Psychology, 89, 71- 81.

Shih, S. S. (2005). Taiwanese sixth graders' achievement goals and their motivation, strategy use, and grades: An examination of the multiple goal perspective. The Elementary School Journal, 106(1), 39-58. doi:10.1086/496906.

Sideridis, G. B. (2003). On the origins of helpless behaviour of students with learning disabilities: Avoidance motivation? International Journal of Educational Research, 39, 497-518.

Spera, C. (2005). A review of the relationship among parenting practices, parenting styles and adolescent school achievement. Educational Research Review, 17(2), 125-146.

Star, M. L. (2011). The relationship between parenting styless, learning autonomy, and scholastic achievement in undergraduate college students (Master's thesis, Buncknell University).

Toyin, A. S., \& Aderemi, O. N. (2013). The psychosocial contributions of parenting style and emotional intelligence to the prediction of violent behaviour among college of education students. European Journal of Educational Studies, 5(1), $19-27$.

Walker, J. M. T. (2010). Looking at teacher practices through the len of parenting style. Journal of Experimental Education, 76(2), 218-240.

Winter, M. C., \& Yaffe, M. (2000). First-year students' adjustment to university life as a function of relationships with parents. Journal of Adolescence, 15(1), 9-38.

Wolters, C. A., Yu, S., \& Pintrich, P. (1996). The relation between goal orientation and students' motivational beliefs and self regulated learning. Learning and Individual Differences, 8, 211-238.

Wolters, C. A. (2004). Advancing achievement goals theory: Using goal structures and goal orientations to predict students' motivation, cognition and achievement. Journal of Educational Psychology, 96, 236-250. 